\title{
Assessment of Bacteriological Quality of Drinking Water from Households of Sarvodaya Nagar, Lucknow, Uttar Pradesh, India
}

\author{
Shilpi Srivastava ${ }^{\circledR 1}$, Saurabh Kashyap ${ }^{\circledR 2}$, Ashish Rawat ${ }^{\circledR 3}$ \\ ${ }^{1}$ Professor, Department of Microbiology, IIMS\&R, Integral University, Lucknow, UP, India, ${ }^{2}$ Associate Professor, Department of Community Medicine, IIMS\&R, Integral \\ University, Lucknow, UP, India, ${ }^{3}$ Research Scholar, Department of Microbiology, IIMS\&R, Integral University, Lucknow, UP, India.
}

\section{Abstract}

Background: In the current scenario, the urbanization is happening at a faster pace and the economy is not able to match at par with urbanization, this In turn is causing problems of unavailability of safe and potable water along with proper sewage system, despecially in urban slums. As a result of the scenario many urban slums are still using poor quality pit latrines and even drawing water from nearby wells, water taps which are not complying with government norms. Space is also a big problem which is being faced by these slums, due to which there is a lack of enough spaces in the houses and nearby areas, therby causing overcrowding. Due to overcrowding, the space between houses, pit latrines, wells, taps and water bodies has decreased and thus the potential of contamination of water bodies by fecal microorganisms has increased drastically. Given the above knowledge, a study is much needed to estimate the presumptive and differential coliform count of water samples from the urban slum area in Lucknow. Subjects \& Methods: A cross-sectional survey was conducted during the period of January to June 2019. Samples were collected from all the taps, hand pumps that were currently in use, along with potable water stored in households of Sarvodaya Nagar (an urban slum area), Lucknow and were processed in the Microbiology department of IIMS\&R, Lucknow. Results: A total of 53(63\%) samples were taken from Public supply, out of which 36(67. 9\%) were found unsatisfactory and 17(32.0\%) were intermediate, were found to be contaminated with Pseudomonas sp., E.coli, Thermotolerent E.coli, Klebsiella Spp. Citrobacter, Enterococcus and Pseudornonas Spp., E.coli, Thermotolerent E.coli, Klebsiella respectively. In the study more than half of the samples were taken from the Public water supply. Out of these about seventy percent were unsatisfactory and were found to be contaminated with Pseudomonas. Conclusion: The proper sanitation, regular treatment, supervision of water sources, arid regular bacteriological assessment of all water sources for drinking should be planned and conducted.

Keywords: Water, Sanitation, Contamination, Sturns, Coli form.

Corresponding Author: Saurabh Kashyap, Associate Professor, Department of Community Medicine, IIMS\&R, Integral University, Lucknow, UP, India.

E-mail: dr.saurabh2000@gmail.com

Received: 30 July 2020

Revised: 28 September 2020

Accepted: 06 October 2020

Published: 30 December 2020

\section{Introduction}

The provision of safe and affordable water supply for everyone is one of the major challenges for people residing in developing countries especially in urban slums, hence a goal has been made to be achieved by 2030. ${ }^{[1]}$ Urban slums constitute one third ie 860 million, of the total population residing in developing countries. ${ }^{2]}$ Urban slums are always under political and legal issues which makes the accessibility of people residing there for clean and safe water a bit difficult. ${ }^{[3,4]}$ Many slums in developing countries are registered by the government. There are few slums in many cities that provide land security. In simpler words, people residing in such slums have some legal property rights and easy access to safe and potable water supply, despite not being owned by them. On the contrary, almost $60 \%$ of urban slum settlements are not notified by the government of India, due to this the government doesn't provide its monetary supports and habitats suffer from poor accessibility of conveyance, piped safe water supply, electricity and sanitary latrines. ${ }^{[5]}$ Many low and middleincome countries namely Kenya, Bangladesh and Nigeria have similar policies of land tenure cooperation and water access for people dwelling in urban slums. ${ }^{[6,7]}$ despite having stringent public health and backings to provide municipal water supplies and sanitary latrines the basic reasons for unavailability of such services is lack of property rights, and to back this provision the high courts also passed a law in support of the urban slums. ${ }^{[4]}$ An accessible and more likely acceptable clean water supply is the basic human need but unfortunately, many people living in urban slums of developing countries 
have poor accessibility to satisfactory and safe water. As per a survey conducted way back in 1996 the people living in periurban slums were been deprived of safe water in urban areas due to speedy urbanization. ${ }^{[8]}$ The stringent policy should be made for safe water supply and appropriate sanitation as it has been suggested by a united nation that due to fast urbanization the problems of these basic needs will be increased drastically between 2000 and 2030. ${ }^{[9]}$ Due to the injudicious disposal of excreta and improper hygiene, the incidence of water-borne diseases like hepatitis B, ascariasis, schistosomiasis, cholera typhoid, polio will increase gradually. According to the world health organization the consumption of contaminated and polluted water in developing countries can account for one-third of total deaths, thereby decreasing the production time to one-tenth. ${ }^{[10]}$ The WHO also stated that almost 22 million people dying of diarrhea and $10 \%$ of the population suffers from parasitic infestation. ${ }^{[11,12]}$ Keeping this background knowledge in view the aim of the study was to determine the quality and extent to which the water is contaminated at the study area, the knowledge of which can be used to take necessary actions by the municipal corporation and Uttar Pradesh Jal Nigam (Indian water utility) in district Lucknow(India). The water sample collected from different regions of Sarvodayanagar were subjected to portability analysts to have an insight into the bacteriological condition of drinking water.

\section{Subjects and Methods}

It was an observational study having a cross-sectional design, conducted from January 2019 to June 2019. Samples were collected from all the taps, hand pumps that were in use during the surveys, along with potable water stored in households of Sarvodaya Nagar (an urban slum area), Lucknow and were processed in the Microbiology department of IIMS\&R. Lucknow. The sample size was calculated with alpha $3 \%$ and power $80 \%$. Informed consent was taken prior to the collection of water samples. Ethical approval was obtained from the Institutional Ethical Committee of Integral University Lucknow. Sterile glass stoppered bottles $(250 \mathrm{~mL})$ were used to collect water samples. Using cotton wool soaked in $70 \%$ ethanol, the outlet of the tap/had-pump were sterilised. The tap was turned on, for maximum flow for two minutes and then $200 \mathrm{ml}$ water was collected under medium flow, cap was replaced after the sample was kept within cool-packs and brought to the laboratory for processing within 6 hours. Samples collected were labelled properly with details like date of collection, time, place including the source from where it has been collected. A structured questionnaire was used to obtain the necessary information from all the 84 selected households. Bacteriological examination was done by Differential coliform count and Presumptive coliforrn count. The presumptive coliforrn count (Multiple tube method) was expressed as the most probable number (MPN) of coliform organisms per $100 \mathrm{~mL}$ of water. Mac Conkey purple broth in single and double strength was added to the bottles or tubes. Durham's tube was to detect gas production. Bromocresol purple was the indicator. A measured amount of water samples were added to tubes containing Mac Conkey purple broth by sterile graduated pipettes as under:

- Of water added to one bottle of $50 \mathrm{~mL}$ double strength medium.

- Of water each-added to 5 tubes or $10 \mathrm{~mL}$ double-strength mcdium.

- Of water each-added to 5 tubes of $5 \mathrm{~mL}$ single strength medium.

Analysis: The data were analysed using SPSS Software.

\section{Results}

A total of 84 water samples from different water sources. $21(25 \%)$ samples were taken from the Submersible pump, 53(63\%) samples were taken from Public supply, 3(3.6\%) samples were taken from $\mathrm{RO} / \mathrm{UV}$ filter and 7(8.3\%) samples were taken from Gravity based purifiers. [Figure 1]

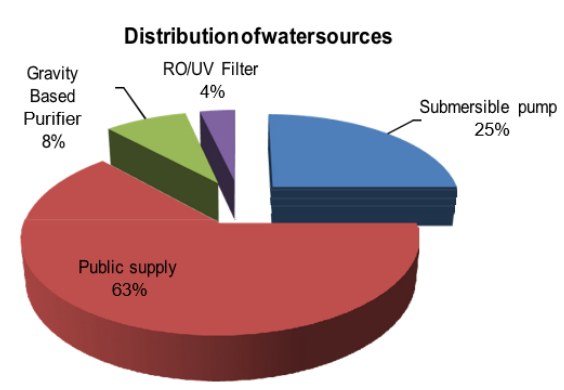

Figure 1: Distribution of water source according to the site.

Out of the total sample $(n=84), 40(47.6 \%)$ were unsatisfactory and not suitable for human consumption whereas, $21(25 \%)$ samples were intermediate, $8(9.5 \%)$ samples were satisfactory and $15(17.8 \%)$ samples were found to be excellent. It is to be noted that in the upper table which is showing the number of unsatisfactory samples is zero for Gravity-based purifier \& $\mathrm{RO} / \mathrm{UV}$ Filters whereas the public supply is the most contaminated followed by the Submersible water is used for drinking purposes. [Table 1]

[Figure 2] showing the percentage of isolates obtained from Submersible pump percentage of Pseudomonas, Thermotolerant E.coli, E.coli, Klebsiella spp. are (57.1\%), (23.8\%), $(28.5 \%)$, and $(4.7 \%)$. From Public supply percentage of 


\begin{tabular}{|c|c|c|c|c|c|}
\hline Source & $\begin{array}{l}\text { Total } \quad \text { sample } \\
\mathrm{n}=84\end{array}$ & $\begin{array}{l}\text { Excellent MPN } \\
(<1)\end{array}$ & $\begin{array}{l}\text { Satisfactory } \\
\text { MPN (1-3) }\end{array}$ & $\begin{array}{l}\text { Intermediate } \\
\text { MPN (4-9) }\end{array}$ & $\begin{array}{l}\text { Unsatisfactory MPN } \\
(>10)\end{array}$ \\
\hline $\begin{array}{l}\text { Submersible } \\
\text { pump }\end{array}$ & $21(25 \%)$ & $9(42.8 \%)$ & $4(19.0 \%)$ & $4(19.0 \%)$ & $4(19.0 \%)$ \\
\hline Public supply & $53(63 \%)$ & 0 & 0 & $17(32.0 \%)$ & $36(67.9 \%)$ \\
\hline $\begin{array}{l}\text { Gravity based } \\
\text { purifier }\end{array}$ & $7(8.3 \%)$ & $4(57.1 \%)$ & $3(42.8 \%)$ & 0 & 0 \\
\hline RO/UV Filter & $3(3.6 \%)$ & $2(66.6 \%)$ & $1(33.3 \%)$ & 0 & 0 \\
\hline
\end{tabular}

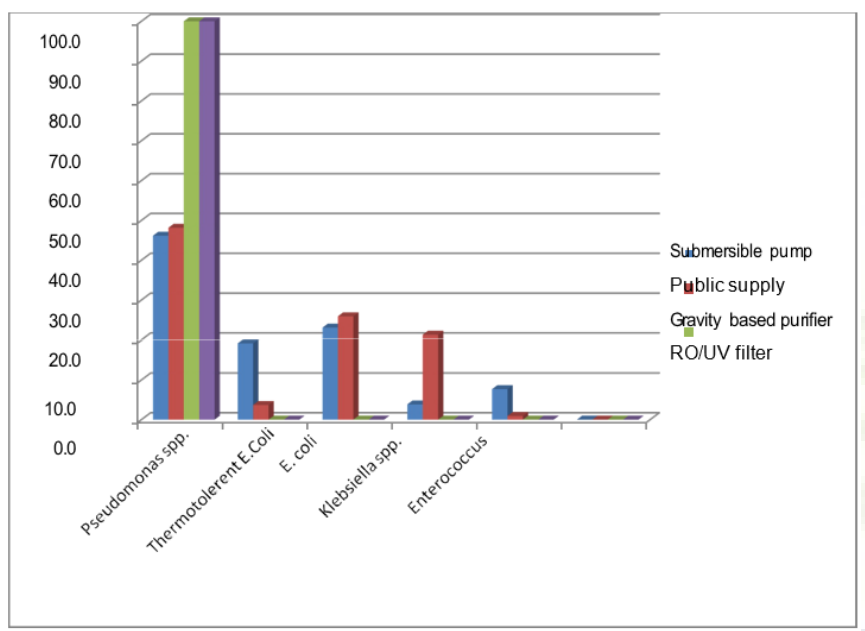

Figure 2: Percentage of isolates from different sources

Pseudomonas, Thermotolerant E. coli, E. coli, Klebsiella spp., and Enterococcus are (98.1\%), (7.5\%), (52.8\%), (43.3\%) and (1.8). Gravity based purifier percentage of Pseudomonas spp. are $(42.8 \%)$ and at the last from RO/UV filter percentage of isolates (33.3\%). [Figure 2]

\section{Discussion}

In our study among 84 samples, $17.9 \%$ were of excellent quality, $9.5 \%$ samples were satisfactory, $25 \%$ were of intermediate quality, and a high number were unsatisfactory or unfit for drinking (47.6\%), Pseudomonas spp., and E.coli were most common isolates. Thakur et al., in his study also found that who have reported that $29.4 \%$ out of total water samples were excellent, $11.76 \%$ were satisfactory, $5.88 \%$ were of intermediate quality, and a huge percentage $(52.94 \%)$ were highly unsatisfactory, they also found that E.coli and Enterobacter aerogenes were present in most of the water samples. ${ }^{[13]}$ Out of 40 unsatisfactory samples 38 (95\%) showed growth of E.coli or Thermotolerent E.coli which indicates recent fecal contamination by human or animal excreta. This is in similarity to the study performed by Balaraman et al., who reported E.coli in 16(94.1\%) out of 17 unsatisfactory samples. ${ }^{[14]}$ Sixty-seven out of 84 samples showed growth of Pseudomonas, one possible reason could be the presence of Pseudomonas in water naturally. According to Bartram et al. ${ }^{[15]}$ and Hardalo et al, ${ }^{[16]}$ Pseudomonas can survive in the environment for a longer period of time and can even multiply in various aquatic habitats. Therefore the presence of this species is not indicative of probable fecal contamination of water source. $47.6 \%$ of samples were unsatisfactory and not suitable for human consumption. This is similar to a study done by Tamble et al, ${ }^{[17]}$ who reported $45.9 \%$ pollution rate of piped water while in a study done by Singh et al, ${ }^{[18]}$ reported $28 \%$ of groundwater supplied through taps was unsatisfactory. In our study, the most common isolate was Pseudomonas followed by E.coli, Klebsiella, Citrobacter and Enterobacter. This is in contradiction with a study done by Chauhan et al, ${ }^{[19]}$ In our study, Public water supply showed a higher level of contamination, which is being followed by water from submersible pumps. Whereas in a study conducted by (Sita et al., submersible pumps showed the highest contaminated source. ${ }^{[20]}$ Our study is in contradiction with the study done by Ngwa-Chrysanthus et al. ${ }^{[21]}$

\section{Conclusion}

More than half of the water samples were taken from Public supply. Out of which about seventy percent were unsatisfactory and were having Pseudomonas sp., E.coli, Thermotolerent E.coli, Klebsiella Spp, Citrobacter, Enterococcus and Pseudomonas Spp., E.coli, Thermotolerent E.coli, Klebsiella respectively as the main contaminants. Hence the water should be properly cleaned and treated by local authorities. These authorities should regularly supervise the water sources for their bacteriological contamination so that diarrhoeal diseases, worm infestation and other diseases could be averted.

\section{References}

1. Omarova A, Tussupova K, Hjorth P, Kalishev M, Dosmagambetova R. Water Supply Challenges in Rural Areas: A Case 
Study from Central Kazakhstan. Int J Environ Res Public Health. 2019;16(5):688. Available from: https://dx.doi.org/10. 3390/ijerph16050688.

2. United Nations Human Settlements Programme. In: Prosperity of cities; 2013. p. 2012-2025.

3. Murthy SL. Land security and the challenges of realizing the human right to water and sanitation in the slums of Mumbai, India. Health Hum Rights. 2012;14(2):61-73.

4. Ernst KC, Phillips BS, Duncan BD. Slums Are Not Places for Children to Live Vulnerabilities, Health Outcomes, and Possible Interventions. Adv Pediatr. 2013;60(1):5387. Available from: https://dx.doi.org/10.1016/j.yapd.2013.04. 005 .

5. Nolan LB, Bloom DE, Subbaraman R. Legal Status and Deprivation in Urban Slums over Two Decades. Econ Polit Wkly. 2018;53(15):47-55. Available from: http://mospi.nic.in/ Mospi New/upload/KI_SLUM report69round 24dec13.pdf.

6. Mudege NN, Zulu EM. Discourses of illegality and exclusion: When water access matters. Global Public Health. 2011;6(3):221-233. Available from: https://dx.doi.org/10. 1080/17441692.2010.487494.

7. Rashid SF. Strategies to reduce exclusion among populations living in urban slum settlements in Bangladesh. J Health Popul Nutr. 2009;27(4):574-586. Available from: https://doi.org/10. 3329/jhpn.v27i4.3403.

8. Kimani-Murage EW, Ngindu AM. Quality of Water the Slum Dwellers Use: The Case of a Kenyan Slum. J Urban Health. 2007;84(6):829-38. Available from: https://dx.doi.org/ 10.1007/s11524-007-9199-x.

9. Kumar GS, Kar SS, Jain A. Health and environmental sanitation in India: Issues for prioritizing control strategies. Indian J Occup Environ Med. 2011;15(3):93-96. Available from: https://dx.doi.org/10.4103/0019-5278.93196.

10. Anand P, Kunnumakara AB, Sundaram C, Harikumar KB, Tharakan ST, Lai OS, et al. Cancer is a Preventable Disease that Requires Major Lifestyle Changes. Pharm Res. 2008;25(9):2097-2116. Available from: https://dx.doi.org/10. 1007/s11095-008-9661-9.

11. Haque R. Human Intestinal Parasites. J Health Popul Nutr. 2007;25(4):387-391.

12. Mokomane M, Kasvosve I, de Melo E, Pernica JM, Goldfarb DM. The global problem of childhood diarrhoeal diseases: emerging strategies in prevention and management. Ther Adv Infect Dis. 2018;5(1):29-43. Available from: https://dx.doi. org/10.1177/2049936117744429.

13. Thakur M, Negi S, Kumar A, Patil S, Kumar A, Sharma N. Prevalence and characterization of water contamination indicator bacteria with special reference to coliforms from drinking water supply in Solan city of Himachal Pradesh. Biol Forum Int J. 2012;4(1):85-94.

14. Malathy BR, Sajeev SK, Thampy S, Guruvayurappan K, P SA. Bacteriological Analysis of Drinking Water by MPN Method from Chennai, India. Int J Environ Sci. 2017;11(7):57-64.

15. Bartram J. Heterotropic plate counts and drinking-water safety; the significance of HPCs for water quality and human health. WHO Emerging Issues in Water and Infectious Disease Series. 2003;

16. Hardalo C, Edberg SC. Pseudomonas aeruginosa: Assessment of Risk from Drinking Water. Crit Rev Microbiol. 1997;23(1):47-75. Available from: https://dx.doi.org/10.3109/ 10408419709115130.

17. Tambe PV, Daswani PG, Mistry NF, Ghadge AA, Antia NH. A community- based bacteriological study of quality of drinkingwater and its feedback to a rural community in Western Maharashtra. J Health Popul Nutr. 2008;26(2):139-150.

18. Singh AK, Gupta VK, Sharma B, Singla B, Kaur P, Walia G. What are we drinking? Assessment of water quality in an urban city of Punjab. J Family Med Prim Care. 2015;4:514-518. Available from: https://dx.doi.org/10.4103/2249-4863.174267.

19. Chauhan A, Goyal P, Varma A, Jindal T. Microbiological evaluation of drinking water sold by roadside vendors of Delhi, India. Appl Water Sci. 2017;7(4):1635-1644. Available from: https://dx.doi.org/10.1007/s13201-015-0315-x.

20. Malhotra S, Sidhu SK, Devi P. Assessment of bacteriological quality of drinking water from various sources in Amritsar district of northern India. J Infect Dev Ctries. 2015;9(08):844848. Available from: https://dx.doi.org/10.3855/jidc.6010.

21. Ngwa NR, Chrysanthus N. Bacteriological Analysis of Well Water Sources in the Bambui Student Residential Area. J Water Resource Prot. 2013;05(11):1013-1017. Available from: https://dx.doi.org/10.4236/jwarp.2013.511106.

Copyright: (C) the author(s), 2020. It is an open-access article distributed under the terms of the Creative Commons Attribution License (CC BY 4.0), which permits authors to retain ownership of the copyright for their content, and allow anyone to download, reuse, reprint, modify, distribute and/or copy the content as long as the original authors and source are cited.

How to cite this article: Srivastava S, Kashyap S, Rawat A. Assessment of Bacteriological Quality of Drinking Water from Households of Sarvodaya Nagar, Lucknow, Uttar Pradesh, India. Asian J. Med. Res. 2020;9(4):7-10.

DOI: dx.doi.org/10.47009/ajmr.2020.9.4.MB2

Source of Support: Nil, Conflict of Interest: None declared. 